\title{
PENGARUH APLIKASI KOMPOS Crotalaria juncea L. TERHADAP KETERSEDIAAN DAN SERAPAN CA, Mg, S OLEH JAGUNG MANIS (Zea mays saccharata Sturt) DI ENTISOL WAJAK, MALANG \\ Effect of Application of Crotalaria juncea L. Compost on Availability and Uptake of $\mathrm{Ca}, \mathrm{Mg}, \mathrm{S}$ by Sweet Corn (Zea mays saccharata Sturt) on an Entisol of Wajak, Malang
}

\author{
Retno Suntari*, Muhammad Abdi Guna Wiyahya \\ Jurusan Tanah, Fakultas Pertanian, Universitas Brawijaya, Malang 65145 \\ *Penulis korespondensi: rsuntari@ub.ac.id
}

\begin{abstract}
Entisol is a type of soil at the initial development stage and has a texture dominated by a sand fraction. This causes a decrease in soil quality and can reduce crop production. The compost of legume plants can improve soil chemical properties. The purpose of this research was to determine the effect of Crotalaria juncea L. compost application on the availability of secondary macronutrients $\mathrm{Ca}, \mathrm{Mg}$, and $\mathrm{S}$, and uptake of $\mathrm{Ca}, \mathrm{Mg}$, and $\mathrm{S}$ by sweet corn plant in Entisol, Wajak. The treatments tested were $\mathrm{C} 0$ (Urea 100\%), C1 (C. juncea compost 100\% + Urea 75\%), C2 (C. juncea compost 100\% + Urea 75\%), C3 (C. juncea compost 100\%), C4 (C. juncea compost 200\%). The five treatments were arranged in a completely randomized design with three replications. The results showed that the application of $C$. juncea compost $\left(20 \mathrm{t} \mathrm{ha}^{-1}\right)$ significantly increased the availability of $\mathrm{Ca}, \mathrm{Mg}$ and $\mathrm{S}$ on 12 weeks by $41.6 \%$, $96.71 \%$ and $133.78 \%$, respectively. The application of $20 \mathrm{t} C$. juncea compost ha $\mathrm{a}^{-1}$ did not significantly increase uptake of $\mathrm{Ca}, \mathrm{Mg}$ and $\mathrm{S}$.
\end{abstract}

Keywords: availability and uptake of Ca Mg S, Crotalaria juncea compost, Entisol, legumes

\section{Pendahuluan}

Entisol merupakan jenis tanah yang baru terbentuk dengan tingkat perkembangan profil tanah awal dan termasuk jenis tanah muda, dari total keseluruhan lahan kering masam di Indonesia sebesar 3,8 juta ha luasan Entisol tersebar di sebagian besar Sumatra, pulau Jawa terutama Jawa Barat, Kalimantan, Bali dan Nusa Tenggara serta Sulawesi (Puslitbangtanak, 2006). Entisol memiliki permasalahan utama yaitu rendahnya unsur hara makro maupun mikro yang tersedia karena sebagian unsur hara masih terikat dalam bentuk mineral. Unsur hara tersebut menjadi semakin sedikit terutama nitrogen dikarenakan Entisol sangat mudah tercuci karena memiliki tekstur yang didominasi fraksi pasir sehingga daya simpan air tanah rendah (Arifin, 2011). Entisol hanya memiliki horizon penciri okhrik yang mana c-organik kurang dari $0,6 \%$ atau bahan organik kurang dari 1\% (Hardjowigeno, 1995).

Tanaman orok-orok (Crotalaria juncea L.) merupakan salah satu jenis tanaman yang dapat digunakan sebagai pupuk organik untuk menambah unsur hara makro dan mikro ke dalam tanah. Tanaman legum ini mampu mengikat $\mathrm{N}$ di udara, dengan bantuan bakteri penambat $\mathrm{N}$ yang dapat menyediakan $\mathrm{N}$ dalam tanah sehingga meningkatkan kesuburan tanah. Aplikasi C. juncea dapat dilakukan dalam bentuk pupuk hijau maupun dalam bentuk kompos. Kompos tanaman C. Juncea dapat menjadi bahan organik tanah sehingga berperan dalam memperbaiki sifat-sifat tanah (Sutejo, 2002). C. juncea mempunyai kandungan unsur hara nitrogen yang tinggi dan pertumbuhan $C$. juncea yang relatif cepat mampu menghasilkan biomassa dengan cepat pula. Saat berumur 14 


\section{Jurnal Tanah dan Sumberdaya Lahan Vol 7 No 2 : 201-208, 2020 e-ISSN:2549-9793, doi: 10.21776/ub.jts1.2020.007.2.3}

HST, tanaman orok-orok mengandung 5,25\% $\mathrm{N}$ dan $69,55 \%$ bahan organik, pada umur 30 HST mengandung $4,29 \% \mathrm{~N}$ dan $66,85 \%$ bahan organik, sedangkan pada saat umur 42 HST mengandung 2,49\% $\mathrm{N}$ dan $66,78 \%$ bahan organik (Noviastuti, 2006).

Tanaman jagung telah menjadi komoditi utama di Indonesia dengan kebutuhan 26,03 juta ton tahun 2017 dan meningkat menjadi 28,61 juta ton pada tahun 2018 (BPS, 2018). Kondisi ini menyebabkan penggunaan pupuk anorganik yang berlebihan dan dijalankan terus-menerus (sumarni, 2014). Usahatani jagung di daerah sentra tanaman jagung menggunakan pupuk anorganik terutama urea dengan dosis yang cukup tinggi dengan kisaran dosis $700-800 \mathrm{~kg}$ $\mathrm{ha}^{-1}$ (Kasim, 2007). Penggunaan pupuk anorganik secara terus-menerus dan berlebihan akan berpengaruh pada penurunan kesuburan tanah yang disebabkan oleh menurunnya kandungan bahan organik tanah, defisiensi unsur hara makro ( $\mathrm{Mg}$ dan $\mathrm{S}$ ) dan defisiensi unsur hara mikro ( $\mathrm{Zn}, \mathrm{Cu})$. Selanjutnya keracunan akibat kelebihan unsur hara mikro Fe, $\mathrm{Mn}$ dan $\mathrm{Al}$ dapat meningkatkan kemasaman tanah $(\mathrm{pH})$ menurun ketersediaan fosfor bagi tanaman serta mamatikan kehidupan mikroorganisme tanah (Syekhfani, 1997). Aplikasi pupuk kompos C. juncea diharapkan dapat meningkatkan ketersediaan unsur hara makro khususnya $\mathrm{Ca}, \mathrm{Mg}, \mathrm{S}$ dan menurunkan penggunaan pupuk anorganik pada tanaman jagung serta meningkatkan serapan $\mathrm{Ca}, \mathrm{Mg}, \mathrm{S}$ pada tanaman jagung manis.

Tujuan penelitian ini adalah untuk mempelajari pengaruh pengaruh aplikasi kompos C. juncea terhadap ketersediaan dan serapan $\mathrm{Ca}, \mathrm{Mg}, \mathrm{S}$ pada jagung manis (Zea mays saccharata Sturt) di Entisol Wajak, Malang.

\section{Metode Penelitian}

Penelitian ini dilakukan pada bulan September 2016 hingga Januari 2017 di rumah kaca Fakultas Pertanian, Universitas Brawijaya, Malang. Analisis sampel dilaksanakan di Laboratorium Kimia Jurusan Tanah Universitas Brawijaya. Penelitan ini terbagi 2 tahap yaitu tahap pertama pengambilan media tanam pada Desa Dadapan, Kecamatan Wajak, Kabupaten Malang. Tahap kedua pembuatan kompos Crotalaria juncea L. yang dilakukan di UPT kompos Universitas Brawijaya, Malang. Penelitian ini menggunakan Rancangan Acak Lengkap (RAL). Penelitian dilakukan dengan 2 seri penelitian yakni plot dengan tanaman dan plot inkubasi. Setiap plot terdiri dari 5 perlakuan dosis dan 3 ulangan sehingga didapatkan 15 kombinasi perlakuan. Penelitian menggunakan menggunakan jagung manis varietas Talenta. Tanah inkubasi menggunakan polibag ukuran $25 \times 15 \mathrm{~cm}$ dan tanaman jagung ditanam pada polibag ukuran $35 \times 35 \mathrm{~cm}$. Semua perlakuan diberi pupuk dasar pada saat sehari sebelum tanam dengan dosis Urea $288 \mathrm{~kg} \mathrm{ha}^{-1}$, SP36 444,45 kg ha-1, KCl $250 \mathrm{~kg} \mathrm{ha}^{-1}$, dan ZA 83,3 kg ha $^{-1}$ (Dierolf et al., 2001). Aplikasi Ca Super dilakukan 7 hari sebelum tanam. Pengamatan yang dilakukan meliputi pengamatan tanaman dan tanah. Data yang yang dikumpulkan terdiri dari pengamatan serapan (12 MST) meliputi: serapan $\mathrm{Ca}, \mathrm{Mg}$, dan $\mathrm{S}$, sedangkan pengamatan parameter tanah (4, 8, 12 MSI) meliputi: ketersediaan $\mathrm{Ca}, \mathrm{Mg}$, dan $\mathrm{S}$ pada tanah inkubasi.

\section{Hasil dan Pembahasan \\ Ketersediaan kalsium (Ca)}

Hasil analisis ragam menunjukkan aplikasi kompos orok-orok berpengaruh nyata pada nilai $\mathrm{Ca}$ yang tersedia dalam tanah inkubasi (Lampiran 6d). Hasil aplikasi kompos pada 4 MSI menunjukkan perlakuan C0 (kontrol) berbeda nyata dengan perlakuan C1 (kompos $C$. rjuncea $100 \%+$ Urea $75 \%$ ) dan C2 (kompos $C$. juncea $100 \%+$ Urea 50\%) namun tidak berbeda nyata dengan perlakuan C3 (kompos C. juncea 100\%) dan C4 (kompos C. juncea 200\%). Nilai ketersediaan $\mathrm{Ca}$ tertinggi pada 8 MSI ditunjukkan oleh perlakuan C2 (kompos C. juncea 100\% + Urea 50\%) dan berbeda sangat nyata dengan perlakuan C1 (kompos C. juncea $100 \%+$ Urea 75\%) maupun C0 (kontrol). Ketersediaan $\mathrm{Ca}$ pada 8 MSI mengalami penurunan pada 12 MSI dengan nilai $\mathrm{Ca}$ terendah ditunjukkan oleh perlakuan $\mathrm{C} 0$ (kontrol) tetapi berbeda sangat nyata dengan ketersedian Ca pada perlakuan C1 (kompos $C$. juncea 100\% + Urea 50\%) dan C4 (kompos C. juncea 200\%). Menurut Ahn (1993), unsur hara $\mathrm{Ca}$ berperan dalam pertumbuhan sel. Unsur hara $\mathrm{Ca}$ ialah komponen penguat dan mempertahankan integritas sel-sel, 


\section{Jurnal Tanah dan Sumberdaya Lahan Vol 7 No 2 : 201-208, 2020 e-ISSN:2549-9793, doi: 10.21776/ub.jts1.2020.007.2.3}

permeabilitas membran serta merawat dinding sel, sehingga ketersediaannya sangat dibutuhkan oleh tanaman. Kalsium yang merupakan hara alkali ketersediaannya berhubungan dengan KTK (Kapasitas Tukar Kation) dan persen KB (Kejenuhan Basa).

Tabel 1. Pengaruh aplikasi kompos C. juncea terhadap ketersediaan Ca.

\begin{tabular}{|c|c|c|c|c|c|c|c|}
\hline \multirow[t]{3}{*}{ Perlakuan } & \multicolumn{4}{|c|}{ Ca-tersedia $\left(\mathrm{cmol} \mathrm{kg}^{-1}\right)$} & \multicolumn{3}{|c|}{ Peningkatan (\%) } \\
\hline & 4 & 8 & & 12 & 4 & 8 & 12 \\
\hline & \multicolumn{7}{|c|}{ MSI (Minggu Setelah Inkubasi) } \\
\hline $\mathrm{C} 0$ & $6,71 \mathrm{a}^{*}$ & 6,37 & $a^{* *}$ & $6,05 \mathrm{a}^{* *}$ & 0,00 & 0,00 & 0,00 \\
\hline $\mathrm{C} 1$ & $7,56 \mathrm{~b}$ & 9,07 & b & $7,82 \mathrm{~b}$ & 12,67 & 42,39 & 29,26 \\
\hline C2 & $7,84 \mathrm{~b}$ & 10,67 & & $7,25 \mathrm{ab}$ & 16,84 & 67,50 & 19,83 \\
\hline C3 & $6,69 \mathrm{a}$ & 8,33 & bc & $6,79 \mathrm{ab}$ & $-0,30$ & 30,77 & 12,23 \\
\hline C4 & $7,17 \mathrm{ab}$ & 9,01 & $\mathrm{bc}$ & $8,54 \mathrm{c}$ & 6,86 & 41,44 & 41,16 \\
\hline
\end{tabular}

Keterangan : Angka-angka pada kolom yang sama diikuti huruf yang berbeda menunjukkan berbeda nyata pada Uji Beda Nyata Terkecil (BNT) 5\%. Perlakuan C0: Urea 100\%; C1: Kompos C. juncea 100\% + Urea 75\%; C2: Kompos C. juncea 100\% + Urea 50\%; C3: Kompos C. juncea 100\%; C4: Kompos C. juncea 200\%. (*) Berpengaruh nyata; (**) Berpengaruh sangat nyata.

Defisiensi Ca terdapat pada kondisi tanah yang sangat masam dengan kejenuhan $\mathrm{Ca}$ yang rendah. Ketersediaan akan meningkat pada $\mathrm{pH}$ 7,0-8,5 kemudian menurun pada $\mathrm{pH}$ di bawah 7,0 maupun di atas $\mathrm{pH} 8,5$. Peningkatan KTK dipengaruhi oleh peningkatan bahan organik di dalam tanah. Menurut Daimon (2006), Crotalaria sp. mengandung senyawa aromatik yang termasuk dalam bentuk cincin siklik dan sesuai dengan yang dikemukakan oleh Syekhfani (1997) bahwa humus yang tersusun dari gugus karboksil dalam bentuk cincin siklik yang memiliki KTK tinggi.

\section{Ketersediaan magnesium (Mg)}

Hasil pengamatan selama 12 MSI menujukkan bahwa ketersediaan magnesium mengalami penurunan seiring bertambahnya masa inkubasi. Mg pada 4 MSI menunjukkan ketersediaan magnesium tertinggi pada perlakuan C3 (kompos C. juncea 100\%) tetapi tidak berbeda nyata dengan perlakuan C4 (kompos C. juncea 200\%). Hal tersebut berbeda dengan Mg-dd pada 8 MSI dan 12 MSI yang menunjukkan bahwa perlakuan C1 (kompos C. juncea 100\% + Urea 75\%), C2 (kompos C. juncea 100\% + Urea 50\%), C3 (kompos C. juncea 100\%), dan C4 (kompos C. juncea 200\%) berbeda nyata dengan perlakuan C0 (kontrol) pada 12 MSI, tetapi pada 8 MSI perlakuan C4 (kompos C. juncea 200\%) menunjukkan nilai $\mathrm{Mg}$-dd tertinggi dengan peningkatan 199,35\%. Ketersediaan Mg pada 8 MSI bila dibandingkan dengan 12 MSI meningkat kembali dengan nilai terendah pada perlakuan C0 (kontrol). Magnesium sangat diperlukan oleh klorofil tanaman, dalam proses fotosintesis berhubungan langsung dalam proses metabolisme fosfor dan pengaktifan enzim pada proses pembentukan karbohidrat. Magnesium diserap dalam bentuk $\mathrm{Mg}^{2+}$ yang ditranslokasikan dari daun tua ke daun muda. Peningkatan ketersediaan $\mathrm{Mg}$ dapat dilakukan dengan penambahan bahan organik yang dapat meningkatkan $\mathrm{pH}$ dan KTK. Aplikasi C. juncea dapat memperbaiki kualitas sifat fisika, kimia dan biologi tanah. Sifat fisika tanah yang diperbaiki ialah kemantapan agregat, sedangkan sifat kimia ialah C-organik, bahan organik, $\mathrm{N}$ total, KTK dan P. Selain itu keragaman patogen tanah dapat diturunkan dan keragaman mikroorganisme bermanfaat ditingkatkan oleh C. juncea (Sumarni, 2014).

\section{Ketersediaan sulfat ( $\left.\mathrm{SO}_{4}^{2-}\right)$}

Secara umum ketersedian unsur hara sulfur selama 12 minggu di tanah inkubasi menunjukkan peningkatan seiring bertambahnya masa inkubasi. Ketersediaan unsur hara sulfur pada 4 MSI dan 8 MSI tidak berpengaruh secara nyata oleh aplikasi kompos orok-orok. Sulfat mengalami peningkatan yang nyata pada 12 MSI. Perlakuan CO (kontrol) dan perlakuan C1 (kompos C. juncea. 100\% + Urea $75 \%$ ) tidak menunjukkan hasil berbeda, namun kedua perlakuan tersebut jika dibandingkan dengan perlakuan yang lain menunjukkan hasil 


\section{Jurnal Tanah dan Sumberdaya Lahan Vol 7 No 2 : 201-208, 2020 e-ISSN:2549-9793, doi: 10.21776/ub.jts1.2020.007.2.3}

yang berbeda. Perlakuan C4 (kompos C. juncea 200\%) menujukkan peningkatan S tersedia tertinggi pada 4, 8, dan 12 MSI berturut-turut $57,46 \%, 66,98 \%$, dan $133,67 \%$. Sulfar anion
$\left(\mathrm{SO}_{4}{ }^{2-}\right)$ tersedia dalam tanah melalui kapasitas tukar anion yang berasosiasi pada fraksi liat, terutama liat kaolinit dan besi serta aluminium oksida.

Tabel 2. Pengaruh aplikasi kompos C. juncea terhadap ketersediaan Mg.

\begin{tabular}{|c|c|c|c|c|c|c|}
\hline \multirow[t]{3}{*}{ Perlakuan } & \multicolumn{3}{|c|}{ Mg-tersedia $\left(\mathrm{cmol} \mathrm{kg}^{-1}\right)$} & \multicolumn{3}{|c|}{ Peningkatan (\%) } \\
\hline & 4 & 8 & 12 & 4 & 8 & 12 \\
\hline & \multicolumn{6}{|c|}{ MSI (Minggu Setelah Inkubasi) } \\
\hline $\mathrm{CO}$ & $6,71 \mathrm{a}^{*}$ & $6,37 a^{* *}$ & $6,05 \mathrm{a}^{*}$ & 0,00 & 0,00 & 0,00 \\
\hline C1 & $7,56 \mathrm{ab}$ & $9,07 \quad a b$ & $7,82 \mathrm{~b}$ & 30,48 & 32,55 & 110,88 \\
\hline C2 & $7,84 \mathrm{abc}$ & $10,67 \mathrm{ab}$ & $7,25 \mathrm{~b}$ & 55,06 & 16,49 & 157,26 \\
\hline C3 & $6,69 \mathrm{c}$ & $8,33 \mathrm{~b}$ & $6,79 \mathrm{~b}$ & 107,15 & 80,75 & 108,61 \\
\hline $\mathrm{C} 4$ & $7,17 \mathrm{bc}$ & $9,01 \mathrm{c}$ & $8,54 \mathrm{~b}$ & 72,12 & 199,36 & 96,71 \\
\hline
\end{tabular}

Keterangan : Angka-angka pada kolom yang sama diikuti huruf yang berbeda menunjukkan berbeda nyata pada Uji Beda Nyata Terkecil (BNT) 5\%. Perlakuan C0: Urea 100\%; C1: Kompos C. juncea 100\% + Urea 75\%; C2: Kompos C. juncea 100\% + Urea 50\%; C3: Kompos C. juncea 100\%; C4: Kompos C. juncea 200\%. (*) Berpengaruh nyata; $(* *)$ Berpengaruh sangat nyata.

Tabel 3. Pengaruh aplikasi kompos C. juncea terhadap ketersediaan $\mathrm{SO}_{4}{ }^{2-}$.

\begin{tabular}{crrrrrr}
\hline \multirow{2}{*}{ Perlakuan } & \multicolumn{5}{c}{ SO $_{4}{ }^{2-}(\mathbf{p p m})$} \\
\cline { 2 - 7 } & $\mathbf{4}$ & $\mathbf{8}$ & $\mathbf{1 2}$ & $\mathbf{4}$ & $\mathbf{8}$ & $\mathbf{1 2}$ \\
\cline { 2 - 7 } & 2,28 & 4,24 & $4,01 \mathrm{a}^{* *}$ & 0,00 & 0,00 & 0,00 \\
C0 & 3,01 & 6,54 & $5,11 \mathrm{a}$ & 32,02 & 54,25 & 27,43 \\
C1 & 3,01 & 4,41 & $7,58 \mathrm{~b}$ & 32,02 & 4,01 & 89,03 \\
C2 & 3,01 & 6,40 & $7,61 \mathrm{~b}$ & 29,39 & 50,94 & 89,78 \\
C3 & 2,95 & $9,37 \mathrm{~b}$ & 57,46 & 66,98 & 133,67 \\
C4 & 3,59 & 7,08 & 9 &
\end{tabular}

Keterangan : Angka-angka pada kolom yang sama diikuti huruf yang berbeda menunjukkan berbeda nyata pada Uji Beda Nyata Terkecil (BNT) 5\%. Perlakuan C0: Urea 100\%; C1: Kompos C. juncea 100\% + Urea 75\%; C2: Kompos C. juncea 100\% + Urea 50\%; C3: Kompos C. juncea 100\%; C4: Kompos C. juncea 200\%. (*) Berpengaruh nyata; (**) Berpengaruh sangat nyata.

Kapasitas Tukar Anion (KTA) akan lebih tinggi pada tanah tropis dengan horison penciri Argilik, termasuk Alfisol, Ultisol serta Oxisol (tanah dengan pelapukan tinggi). Efektifitas pelepasan sulfur juga dapat dipengaruhi oleh bahan organik, tingkat mineralisasi yang tergantung pada kelembaban, suhu dan aktifitas mikrobiologi dalam tanah (Ahn, 1993). Menurut Mathot (2009) ketersediaan sulfur akan sangat tergantung pada keadaan bahan organiknya. Tanah yang memiliki bahan organik yang tinggi seperti hutan akan menyediakan sulfur lebih tinggi dan cukup bagi tanaman dibandingkan dengan tanah dengan bahan organik rendah, seperti padang rumput saat musim kemarau. Aplikasi bahan organik menjadi penting dalam peningkatan ketersediaan sulfur di dalam tanah, hal tersebut ditunjukkan dari hasil yang nyata akibat aplikasi kompos C. juncea pada 12 MSI dengan peningkatan $133,67 \%$. Penelitian yang dilakukan oleh Lemonowicz et al. (2013), menunjukkan bahwa pemberian pupuk kandang pada lahan gandum di musim dingin meningkatkan kandungan sulfur sebesar 38\% dibandingkan dengan perlakuan tanpa pupuk kandang. Saviozzi et al. (2005) dalam penelitiannya juga mendapatkan hasil bahwa aplikasi pupuk kendang dan kompos sampah hijau dapat meningkatkan persentase mineralisasi S di dalam tanah sebesar 1,3-8,5\% dibandingkan tanpa perlakuan. 


\section{Jurnal Tanah dan Sumberdaya Lahan Vol 7 No 2 : 201-208, 2020 e-ISSN:2549-9793, doi: 10.21776/ub.jts1.2020.007.2.3}

\section{Serapan kalsium (Ca)}

Aplikasi kompos C. juncea secara umum tidak memberikan hasil yang nyata terhadap serapan $\mathrm{Ca}$ tanaman. Penelitian terkait penyerapan hara Ca secara umum diketahui bahwa ion $\mathrm{Ca}^{2+}$ terserap lambat oleh jaringan tanaman, dan sebagian besar non-metabolik. Serapan ion $\mathrm{Ca}^{2+}$ yang rendah terjadi pada akar tanaman seperti gandum, kedelai, kacang hijau, kacang polong dan soba (Leggett, 1967). Penelitan lain yang dilakukan oleh Handley dan Overstreet (1961) menemukan bahwa jaringan akar tanaman jagung akan mampu menyerap ion $\mathrm{Ca}^{2+}$ tinggi jika keadaan KTK di dalam tanah juga tinggi. Kalsium (Ca) rata-rata menyusun $0,5 \%$ tubuh tanaman, banyak terdapat dalam daun dan pada tanaman mengendap sebagai Ca-oksalat dalam sel-sel. Datnoff et al. (1990) menunjukkan bahwa Ca mampu merangsang penyerbukan dan pertumbuhan tanaman, mengaktifkan sejumlah enzim yang berfungsi dalam mitosis, divisi dan elongasi sel-sel, serta berperan langsung dalam pemantapan dan sebagai penyusun kromosom.

Tabel 4. Pengaruh aplikasi kompos C. juncea terhadap serapan Ca.

\begin{tabular}{cccc}
\hline Perlakuan & Kadar Ca (\%) & Serapan Ca $\left(\mathbf{g}_{\text {tanaman }}^{-\mathbf{1}}\right)$ & Peningkatan $\mathbf{~ ( \% )}$ \\
\hline C0 & 1,09 & 170,98 & 0 \\
C1 & 1,57 & 283,55 & 65,84 \\
C2 & 1,53 & 250,67 & 46,61 \\
C3 & 1,11 & 182,97 & 7,01 \\
C4 & 1,73 & 238,25 & 39,34 \\
\hline
\end{tabular}

Keterangan : Angka-angka pada kolom yang sama diikuti huruf yang sama menunjukkan tidak berpengaruh nyata pada Uji Beda Nyata Terkecil (BNT) 5\%. Perlakuan C0: Urea 100\%; C1: Kompos C. juncea 100\% + Urea 75\%; C2: Kompos C. juncea 100\% + Urea 50\%; C3: Kompos C. juncea 100\%; C4: Kompos C. juncea 200\%.

Pengaruh nilai $\mathrm{pH}$ tanah terhadap ketersedian kalsium juga akan mempengaruhi jaringan tanaman menyerap hara $\mathrm{Ca}$ dari dalam tanah. Mass (1968) menemukan bahwa efek nilai $\mathrm{pH}$ terhadap penyerapan ion $\mathrm{Ca}^{2+}$ yang terjadi selama 24 jam meningkat seiring adanya kenaikan $\mathrm{pH}$. Variasi nilai $\mathrm{pH}$ dari 3.0 hingga 3.85, 4.0 hingga 4.1, 4.5 hingga 4.65, 4.9 hingga 5.1, 5.5 hingga 5.7, 6.0 hingga 6.2, dan 6.5 hingga 6.9 menunjukkan bahwa penyerapan kalsium oleh akar tanaman jagung akan terhambat oleh ion $\mathrm{H}^{+}$pada $\mathrm{pH} 3.0$ hingga 5.0.

\section{Serapan magnesium (Mg)}

Magnesium menyusun rata-rata $0,2 \%$ bagian tanaman, sebagian besar terdapat di daun dan seringkali dalam proporsi cukup banyak pada biji padi, jagung, sorghum, kedelai dan kacang tanah. Unsur hara magnesium dibutuhkan dalam aktivitas enzim yang berperan dalam metabolisme karbohidrat, terutama dalam siklus asam sitrat yang berperan penting dalam respirasi sel. Kekurangan hara magnesium ditandai dengan gejala klorosis di antara tulang daun tua yang tetap hijau, kemudian menguning atau lembayung kemerahan, selanjutnya menjadi coklat dan nekrotik (Hanafiah, 2012). Hasil kadar dan serapan magnesium oleh jagung manis setelah pemberian kompos C. juncea tidak menunjukkan perbedaan yang nyata terhadap serapan Mg. Serapan hara magnesium oleh tanaman sangat dipengaruhi oleh keadaan tanah dan KTK yang dimiliki, sesuai dengan penelitian yang dilakukan oleh Heijden et al. (2011) mengatakan bahwa percobaan penelusuran isotop Ca dan $\mathrm{Mg}$ sebagai sumber hara bagi akar tanaman akan tersedia pada keadaan larutan tanah dan KTK berada pada keadaan ekuilibrium. Magnesium merupakan hara yang mobile atau hara yang mudah bergerak. Akar tanaman menyerap hara $\mathrm{Mg}$ melalui rambut akar yang kemudian ditranslokasikan ke daun-daun tanaman. Keadaan Mg yang mudah bergerak ini akan mengakibatkan hara tersebut dapat tersedia cepat bagi akar tanaman untuk diserap, atau sebaliknya yaitu akan mudah hilang dari tanah (Martinez-Meza dan Whitford, 1997). Penelitian lain yang dilakukan oleh Marschner (2003) menemukan dalam siklus $\mathrm{Mg}$ akan terjadi melalui aliran dalam floem dan jika aliran ini terhambat maka serapan $\mathrm{Mg}$ akan berkurang. Serapan akar terhadap hara Mg lebih rendah dibandingkan hara $\mathrm{Ca}$, difusi akan $\mathrm{Mg}$ juga 
ditemukan lebih rendah dibandingkan kalsium (Metzner et al., 2010).

Tabel 5. Pengaruh aplikasi kompos C. juncea terhadap serapan Mg.

\begin{tabular}{cccc}
\hline Perlakuan & Kadar Mg (\%) & Serapan $\mathbf{M g}\left(\mathbf{g} \mathbf{t a n}^{-1}\right)$ & Peningkatan $\mathbf{( \% )}$ \\
\hline C0 & 0,47 & 67,62 & 0 \\
C1 & 0,27 & 51,16 & $-24,34$ \\
C2 & 0,59 & 96,05 & 42,04 \\
C3 & 0,52 & 83,4 & 23,34 \\
C4 & 0,46 & 96,76 & 43,06 \\
\hline
\end{tabular}

Keterangan : Angka-angka pada kolom yang sama diikuti huruf yang sama menunjukkan tidak berpengaruh nyata pada Uji Beda Nyata Terkecil (BNT) 5\%. Perlakuan C0: Urea 100\%; C1: Kompos C. juncea 100\% + Urea 75\%; C2: Kompos C. juncea 100\% + Urea 50\%; C3: Kompos C. juncea 100\%; C4: Kompos C. juncea 200\%.

\section{Serapan sulfur (S)}

Efisiensi tanaman dalam menyerap sulfur dari dalam tanah berbeda-beda. Tanah dengan kandungan bahan organik kurang dari 1,2-1,5\% membutuhkan pemupukan sulfur (Saviozzi et al., 2005). Tanaman menyerap sulfur berasal dari 3 sumber, pertama ialah sulfur yang terkandung dalam mineral tanah, sulfur yang terkandung dalam atmosfer dan sulfur yang terkandung pada bahan organik. Hasil kadar sulfat tanaman menunjukkan nilai yang nyata pada perlakuan C4 (kompos C. juncea 200\%) dibandingkan dengan perlakuan lainnya. Perlakuan C4 (kompos C. juncea 200\%) merupakan perlakuan dengan nilai serapan sulfat tertinggi. Bao et al. (2010) menyatakan bahwa konsentrasi S sangat berbeda pada pupuk kompos. Selama pengomposan, konsentrasi $\mathrm{S}$ yang tersedia meningkat diawal periode pengomposan, $\mathrm{S}$ mencapai konsentrasi tertinggi pada kompos 28 hari.

Tabel 6. Serapan sulfur (S).

\begin{tabular}{cccc}
\hline Perlakuan & Kadar S (\%) & Serapan S $\left.\mathbf{( g} \mathbf{~ t a n}^{-1}\right)$ & Peningkatan $\mathbf{~ ( \% )}$ \\
\hline C0 & $0,013 \mathrm{a}^{*}$ & 2,09 & 0 \\
C1 & $0,014 \mathrm{a}$ & 2,55 & 22,04 \\
C2 & $0,013 \mathrm{a}$ & 2,15 & 2,63 \\
C3 & $0,013 \mathrm{a}$ & 2,33 & 11,19 \\
C4 & $0,019 \mathrm{~b}$ & 3,77 & 80,42 \\
\hline
\end{tabular}

Keterangan : Angka-angka pada kolom yang sama diikuti huruf yang berbeda menunjukkan berbeda nyata pada Uji Beda Nyata Terkecil (BNT) 5\%. Perlakuan C0: Urea 100\%; C1: Kompos C. juncea 100\% + Urea 75\%; C2: Kompos C. juncea 100\% + Urea 50\%; C3: Kompos C. juncea 100\%; C4: Kompos C. juncea 200\%. (*) Berpengaruh nyata; (**) Berpengaruh sangat nyata.

Pengomposan terbukti mampu menyediakan bahan aktif dalam meningkatkan struktur tanah saat pengolahan tanah dan meningkatkan produksi kering tanaman pada tanah padang rumput (grassland) karena kandungan bahan organiknya yang tinggi serta mampu menyediakan unsur hara yang penting bagi tanaman sebagai pupuk. Sejalan dengan penelitian yang dilakukan Lemanowicz dan ziomek (2010) bahwa ditemukan peningkatan kandungan sulfat di Luvisol pada peningkatan dosis pupuk kompos hasil panen yang diberikan.
Kenaikan terbesar kandungan sulfur tersebut dilaporkan di tanah yang diambil dari perlakuan pupuk alami dengan dosis $60 \mathrm{t} \mathrm{ha}^{-1}$ dimana kenaikan kadar sulfat sebesar $26 \%$ dibandingkan dengan perlakuan tanpa pupuk kompos. Serapan sulfur berkisar antara 0,03-2 $\mathrm{mmol} \mathrm{g}^{-1}$ berat kering, tergantung pada jenis spesies tanaman (Durenkamp dan De Kok, 2004). Sesuai dengan pernyataan Abdallah et al. (2010) pada kondisi lapangan, ketersediaan sulfur untuk pertumbuhan dan perkembangan tanaman sangat dipengaruhi oleh ketersediaan 


\section{Jurnal Tanah dan Sumberdaya Lahan Vol 7 No 2 : 201-208, 2020 e-ISSN:2549-9793, doi: 10.21776/ub.jts1.2020.007.2.3}

sulfur di dalam tanah, pola curah hujan, dan jumlah gas $\mathrm{SO}_{2}$ di atmosfer.

\section{Kesimpulan}

Aplikasi 20 t kompos C. juncea ha- $\mathrm{ha}^{-1}$ mampu meningkatkan ketersediaan $\mathrm{Ca}, \mathrm{Mg}$ dan $\mathrm{SO}_{4}^{2-}$ pada 12 MSI berturut-turut sebesar 41,6\%, $96,71 \%$ dan $133,78 \%$ dibanding perlakuan urea $288 \mathrm{~kg} \mathrm{ha}{ }^{-1}$. Namun demikian, aplikasi $20 \mathrm{t}$ kompos C. juncea ha $\mathrm{a}^{-1}$ tidak mampu meningkatkan serapan $\mathrm{Ca}, \mathrm{Mg}$ dan S.

\section{Daftar Pustaka}

Abdallah, M., Dubousset, L., Meuriot, F., Etienne, P., Avice, J.C. and Ourry, A. 2010. Effect of mineral sulphur availability on nitrogen and sulphur uptake and remobilization during the vegetative growth of Brassica napus L. Journal of Experimental Botany 61(10): 2635-2646.

Ahn, P.M. 1993. Tropical Soils and Fertilizer Use. Scientific and Technical. UK : London. p 263.

Arifin, Z. 2011. Analisis nilai indeks kualitas tanah Entisol pada penggunaan lahan yang berbeda. Agroteksos 21 (1): 47-51.

Badan Pusat Statistik. 2018. Produksi Padi dan Palawija. Diakses pada tanggal 30 April 2019.

Bao, L., Shu Tian, L. and Zhou, W. 2001. Dynamics of soil organic sulfur mineralization and affecting factors. Acta Pedologica Sinica 38: 184-192.

Daimon, H. 2006. Traits of the genus Crotalaria used as green manure legume on sustainable cropping systems. Japan Agricultural Research Quarterly 40 (4): 299-305.

Datnoff, L., Snyder, R.N.R. and Jones, D.B. 1990. Evaluation of calcium silicate slag and nitrogen on brown spot, neck rot, and sheath blight development on rice, 1988. Biological and Cultural Tests for Control of Plant Diseases 5:6574.

Dierolf, T.S., Fairhurst, T.H. and Mutert, E.W. 2001. Soil Fertility Kit: a Tool Kit for Acid, Upland Soil Fertility Management in Southeast Asia. Potash and Phosphate Institute of Canada, Potash and Phosphate Institute. Food and Agriculture Organisation and Gesellschaft fur Technische Zusammenarbeit.

Durenkamp, M. and de Kok, L.J. 2004. Impact of pedospheric and atmospheric sulphur nutrition on sulphur metabolism of Allium cepa L., a species with a potential sink capacity for secondary sulphur compounds. Journal of Experimental Botany 55: 1821-1830.
Hanafiah, K.A. 2012. Dasar-dasar Ilmu Tanah. Rajawali Pers. Jakarta. p 386.

Handley, R. and Overstreet, R. 1961. Uptake of calcium and chlorine in roots of Zea mays. Plant Physiology 36: 766-774.

Hardjowigeno, S. 1995. Klasifikasi Tanah dan Pedogenesis. Akademika Pressindo. Jakarta. p 353.

Heijden G.V.D., Legout, A., Nicolas, M., Ulrich, E., Johnson, D.W. and Dambrine, E. 2011. Longterm sustainability of forest ecosystems on sandstone in the Vosges Mountains (France) facing atmospheric deposition and silvicultural change. Forest Ecology and Management 261:730-738.

Kasim, F. 2007. Analisis Varians dan Heritabilitas Ketahanan Galur Jagung Rekombinan terhadap Penyakit Bulai. Penelitian Pertanian Tanaman Pangan. pp. 31-35.

Leggett, J.E. and Gilbert, W.A. 1967. Localization of the Ca-mediated apparent ion selectivity in the cross-sectional volume of soybean roots. Plant Physiology 42: 1658-1664.

Lemanowicz, J. and Siwik-Ziomek, A. 2010. Concentrations of available phosphorus and sulphur and activities of some hydrolytic enzymes in a luvisoil fertilized with farmyard manure and nitrogen. Polish Journal of Soil Science 43(1): 37-47.

Lemanowicz, J., Siwik-Ziomek, A. and Koper, K. 2013. Effects of Farmyard Manure and Nitrogen Fertilizers on Mobility of Phosphorus and Sulphur in Wheat and Activity of Selected Hydrolases in Soil. Department of Soil Science Protection. University of Technology and Life Sciences. Bydgoszcz. Poland.

Marschner, P., Kandeler, K. and Marschner, B. 2003. Structure and function of the soil microbial community in a long-term fertilizer experiment. Soil Biology and Biochemistry 35: 453-461.

Martinez-Meza, E. and Whitford, W.G. 1996. Stemflow throughfall and channelization of stemflow by roots in three Chinhuahuan desert shrubs. Journal of Arid Environments 32: 271287.

Mass, E.V. 1968. Calcium Uptake by Excised Maize Root and Interactions with Alkali Cations. USDA. Maryland.

Mathot, M.L. and Thélier-Huché, R.L. 2009. Sulphur and nitrogen content as sulphur deficiency indicator for grasses. European Journal of Agronomy 30: 172-176.

Metzner, R.T., Breuer, M.R., Blumler, U., Schurr, P., Schneider, H.U. and Schroeder, W.H. 2010. Contrasting dynamics of water and mineral nutrients in stems shown by stable isotope tracers 
Jurnal Tanah dan Sumberdaya Lahan Vol 7 No 2 : 201-208, 2020

e-ISSN:2549-9793, doi: 10.21776/ub.jts1.2020.007.2.3

and cryo-SIMS. Plant Cell and Environment 33:13-14.

Noviastuti, E.T. 2006. Pengaruh jarak tanam dan jumlah tanaman per lubang tanam pada pertumbuhan dan hasil tanaman orok-orok (Crotalaria juncea L.). Jurnal Produksi Tanaman 12 (1): 64-75.

Puslitbangtanak. 2006. Atlas Sumber Daya Tanah Eksplorasi Indonesia Skala 1:1.000.000. Pusat Penelitian dan Pengembangan Tanah dan Agroklimat, Bogor.

Saviozzi, A., Cardelli, R., Cipolli, S., Levi-Minzi, R. and Riffaldi, R. 2005. Sulphur mineralization kinetics of cattle manure and green waste compost in soils. Waste Management \& Research 24: 545-551.
Sumarni, T. 2014. Upaya Optimalisasi Kesuburan Tanah melalui Pupuk Hijau Orok-Orok (Crotalaria juncea) pada Pertanaman Jagung (Zea mays L.). Prosiding Seminar Nasional Lahan Suboptimal. Palembang. pp 368 - 372.

Sutejo, M.M. 2002. Pupuk dan Cara Penggunaan. Jakarta : Rineka Cipta.

Syekhfani. 1997. Hara-Air-Tanah-Tanaman. Jurusan Tanah. FP. Universitas Brawijaya. Malang. pp 114. 